\title{
A survey of parasitoids from Greece with new associations
}

\author{
Nickolas G. Kavallieratos', Saša S. Stanković로 , Martin Schwarz \\ Eleftherios Alissandrakis ${ }^{4}$, Christos G. Athanassiou ${ }^{5}$, George D. Floros ${ }^{6}$, \\ Vladimir Žikić
}

I Laboratory of Agricultural Zoology and Entomology, Department of Crop Science, Agricultural University of Athens, 75 Iera Odos str., 11855, Athens, Attica, Greece 2 Faculty of Sciences and Mathematics, Department of Biology and Ecology, University of Niš, Višegradska 33, 18000, Niš, Serbia 3 Biologiezentrum, Johann Wilhelm Klein Straße 73, 4040, Linz, Austria 4 Laboratory of Entomology and Pesticide Science, Department of Agriculture, Technological Educational Institute of Crete, P.O. Box 1939, 71004, Heraklion, Crete, Greece 5 Laboratory of Entomology and Agricultural Zoology, Department of Agriculture, Crop Production and Rural Environment, University of Thessaly, Phytokou Street, 38446, Nea Ionia, Magnissia, Greece 6 Laboratory of Applied Zoology and Parasitology, School of Agriculture, Aristotle University of Thessaloniki, 54124, Thessaloniki, Greece

Corresponding author: Nickolas G. Kavallieratos (nick_kaval@aua.gr)

Academic editor: C. van Achterberg| Received 27 September 2018|Accepted 24 October 2018| Published 15 January 2019

http://zoobank.org/14F2A4FD-04C8-4D6C-9AD0-31B3C2D91CBF

Citation: Kavallieratos NG, Stanković SS, Schwarz M, Alissandrakis E, Athanassiou CG, Floros GD, Žikić V (2019) A survey of parasitoids from Greece with new associations. ZooKeys 817: 25-40. https://doi.org/10.3897/ zookeys.817.30119

\begin{abstract}
We report 22 parasitoid species from Greece that have emerged from their hosts belonging to Blattodea, Coleoptera, Hymenoptera and Lepidoptera, including 12 Braconidae, one Eulophidae, one Evaniidae, seven Ichneumonidae, and one Tachinidae. Nine parasitoids are reported for the first time in Greece, i.e., three Ichneumonidae: Campoplex difformis (Gmelin, 1790), Gelis albipalpus (Thomson, 1884), and Lysibia tenax Townes, 1983; five Braconidae: Charmon cruentatus Haliday, 1833, Dendrosoter protuberans (Nees, 1834), Dolichogenidea longipalpis (Reinhard, 1880), Ecphylus silesiacus (Ratzeburg, 1848), and Spathius curvicaudis Ratzeburg, 1844; and one Eulophidae: Melittobia acasta (Walker, 1839). Nine of the 23 recorded parasitoid-host associations are new. These findings are discussed in relation to the overall related parasitoid-host associations in the target area, as well as the potential of parasitoid use in the biological control of pests.
\end{abstract}

\section{Keywords}

Balkans, field pests, natural enemies, urban pests

Copyright Nickolas G. Kavallieratos et al. This is an open access article distributed under the terms of the Creative Commons Attribution License (CC BY 4.0), which permits unrestricted use, distribution, and reproduction in any medium, provided the original author and source are credited. 


\section{Introduction}

Parasitoids, especially those belonging to Hymenoptera, are important elements of agroecosystems (Godfray 1994). Faunistic surveys of parasitoids constitute the major baselines upon which further applicative studies are based (Tomanović et al. 2014; Petrović et al. 2019). Many pest species, especially lepidopterans, are prone to increase their abundance if conditions are favorable and inflict significant hazards in agriculture and forestry (Elkinton and Liebhold 1990; Devetak et al. 2014). As many parasitoids are able to attack several host species or to specialize on a certain host species, their population dynamics depends on their hosts' abundance, and thus, they are of major importance in controlling pests (Hassell 1980; Hassell and May 1986; Barbosa 1998; Gagić et al. 2016). Systematic investigations of parasitoid fauna in Greece, except for Aphidiinae (Hymenoptera: Braconidae) (Kavallieratos et al. 2004, 2006, 2008, 2013, 2016), have scarcely been conducted. In fact, some surveys of the parasitoid spectrum in Greece in various host species, with the exception of Aphidiinae, have been initiated only during the last years. For example, Kolarov (2007) catalogued the Ichneumonidae (Hymenoptera) of Greece, Papp (2007) presented a list of Braconidae, and Zeegers (2017) provided information on some Tachinidae (Diptera). Other studies are mostly related to particular subgroups of parasitoids. For instance, Tsankov et al. (1999) reported egg parasitoids of Thaumetopoea pityocampa (Denis \& Schiffermüller, 1775) (Lepidoptera: Notodontidae), Anagnou Veroniki et al. (2006) studied the parasitization of Phyllocnistis citrella Stainton, 1856 (Lepidoptera: Gracillariidae), Žikić et al. (2017) revealed the parasitoids of two serious pests in forestry, Lymantria dispar (L., 1758) (Lepidoptera: Erebidae) and Malacosoma neustria (L., 1758) (Lepidoptera: Lasiocampidae), and Alissandrakis et al. (2018) investigated the parasitoid complex that is related to Prays oleae (Bernard, 1788) (Lepidoptera: Praydidae). Considering the lack of information on the spectrum of parasitoids of noxious insects in Greece, the objective of our study was to conduct a survey and shed light on the associations between hymenopterous or dipterous parasitoids and their field or urban hosts in the country.

\section{Materials and methods}

The samples were collected in several localities on the Greek mainland (central Greece, Epirus, Macedonia, Peloponnese, Thrace) and the island of Crete (Fig. 1). The insect material was collected either with or without visible signs of parasitism. Insect specimens were collected from field or urban environments, and then separately placed in plastic containers covered with nylon mesh, transferred to the laboratory and reared at $25^{\circ} \mathrm{C}$ until parasitoid emergence. When host insects were found on plants, voucher samples of the plants were kept in herbariums and later identified by Prof. Bojan Zlatković (Department of Biology and Ecology, University of Niš). To collect specimens of Ptosima undecimmaculata (Herbst, 1784) (Coleoptera: Buprestidae) and 


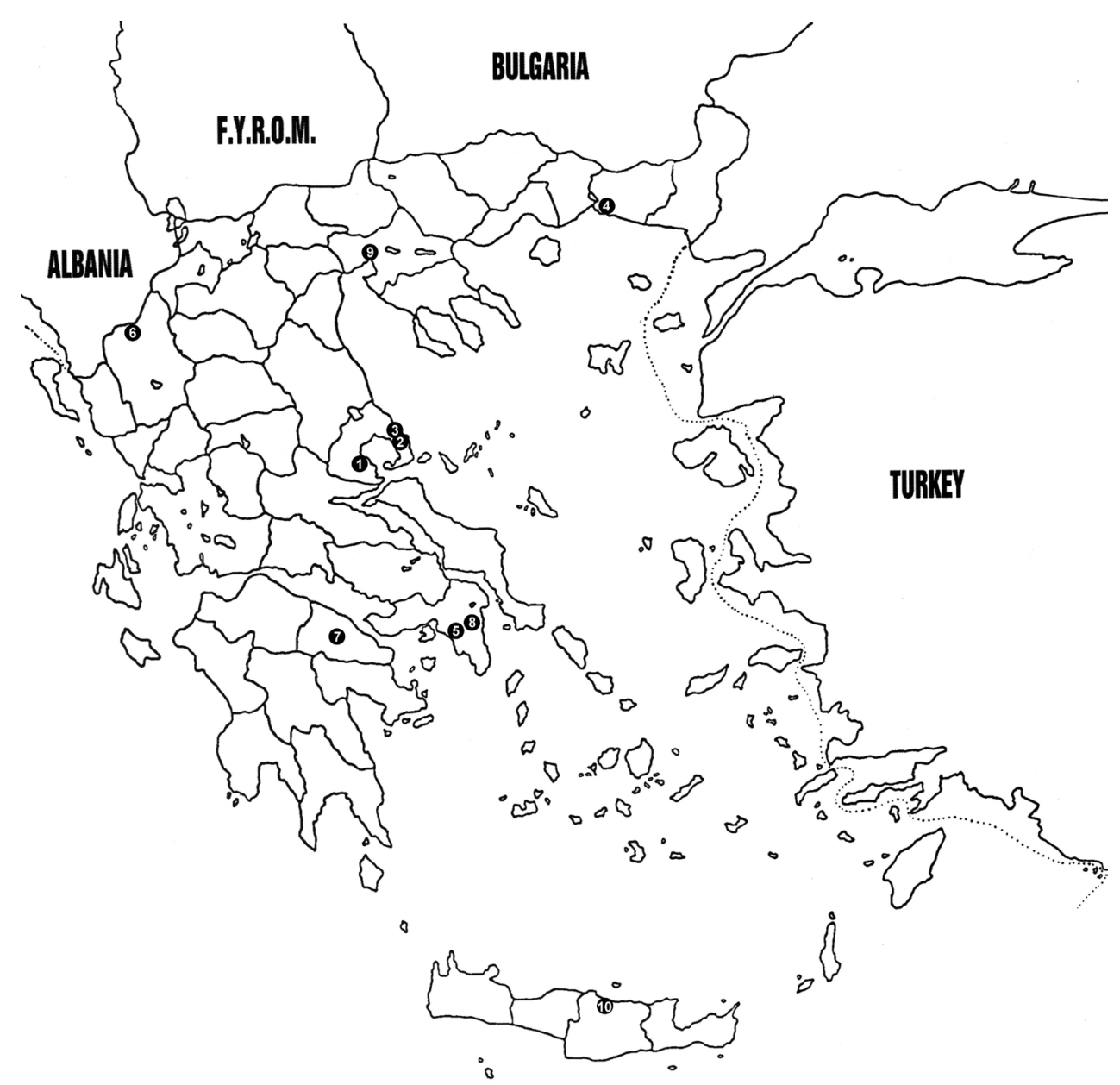

Figure I. Investigated areas marked on the map of Greece: I Almyros (Thessaly) $\mathbf{2}$ Agios Ioannis (Thessaly) 3 Agrioleukes (Thessaly) 4 Arogi (Thrace) 5 Athens (central Greece) 6 Grammos (Epirus) 7 Nemea (Peloponnese) 8 Tatoi (central Greece) 9 Thessaloniki (Macedonia) 10 Voutes (Crete).

Scolytus rugulosus (Müller, 1818) (Coleoptera: Curculionidae), infested wood was cut into small pieces. Then, larvae were very carefully removed, put in plastic containers and kept in the same conditions as above. As soon as the adult parasitoids were emerged, they were captured using an aspirator and killed into vials containing 70\% ethyl alcohol. They were then slide-mounted for detailed examination. Specimens for slides were washed in distilled water, boiled in $10 \% \mathrm{KOH}$ for 2 minutes, rewashed, and then placed in a drop of Faure-Berlese medium (Krantz 1978) for dissection or whole mounting. External morphology was studied using an Olympus SZX9 (zoom ratio 9; total magnification 12.6-114.0×) (Olympus Corporation, Tokyo, Japan) or a Zeiss Discovery V8 (zoom ratio 8; total magnification 10.0-80.0×) (Carl Zeiss MicroImaging $\mathrm{GmbH}$, Göttingen, Germany) stereomicroscopes. The identification of 
parasitoids was based on Tobias and Jakimavicius (1986), Tschorsnig and Herting (1994), Broad (2011), while the host identifications were conducted by Prof. Josef J. De Freina (Museum Witt, Munich, Germany) on the basis of larval morphology. The material was deposited in the insect collection of the Laboratory of Agricultural Zoology of Entomology, Agricultural University of Athens, Greece, the Laboratory of Entomology, Department of Agriculture, Technological Educational Institute of Crete, Greece, and the Faculty of Sciences and Mathematics, Department of Biology and Ecology, University of Niš, Serbia. Nomenclature of hosts is based on Goulet and Huber (1993). In the following results, new records of parasitoids for Greece are marked with an asterisk $\left(^{*}\right)$ in front of each parasitoid name while new parasitoid-host associations are indicated with a dagger $(\dagger)$ in front of each host name. Dates indicate the time when the hosts were collected.

\section{Results}

The identifications of adult parasitoids which emerged from their hosts, revealed 22 species belonging to 5 families. The most numerous were those of the family Braconidae (12 species) followed by Ichneumonidae (7 species). Twenty-three parasitoid-host associations, nine of which were not previously known, are listed in detail below. Nine parasitoid species are recorded for the first time from Greece.

\section{Family Braconidae \\ Subfamily Brachistinae}

Triaspis thoracica (Curtis, 1860)

Material examined. 13ㅇ, 18 $\hat{0}$, Macedonia, Thessaloniki $\left(40^{\circ} 37^{\prime} 58.07^{\prime \prime} \mathrm{N}\right.$, 2257'28.47"E), 01 March 2016, leg. D. Koveos. Host: Bruchus pisorum (L., 1758)

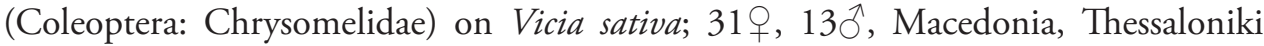
(40³7'58.07"N, 2257'28.47"E), 01 March 2016, leg. D. Koveos. Host: Bruchus pisorum (L., 1758) (Coleoptera: Chrysomelidae) on Vicia peregrina.

\section{Subfamily Charmontinae}

*Charmon cruentatus Haliday, 1833

Material examined. 2q, Thessaly, Almyros (39 $\left.{ }^{\circ} 10^{\prime} 34.39^{\prime \prime} \mathrm{N}, 22^{\circ} 45^{\prime} 17.46 " \mathrm{E}\right), 11$ May 2016, leg. S. Stanković. Host: †Tortrix viridana L., 1758 (Lepidoptera: Tortricidae) on Quercus pubescens. 


\section{Subfamily Cheloninae}

Chelonus (Microchelonus) sulcatus Jurine, 1807

Material examined. 2q, $10^{\widehat{ }}$, Macedonia, Thessaloniki $\left(40^{\circ} 37^{\prime} 55.03^{\prime \prime N}\right.$, $22^{\circ} 57^{\prime} 25.57^{\prime E}$ ), 15 July 2002, leg. N. G. Kavallieratos. Host: Prays citri (Millière, 1873) (Lepidoptera: Praydidae) on Citrus sinensis.

\section{Subfamily Doryctinae}

\section{*Dendrosoter protuberans (Nees, 1834)}

Material examined. 1 ㅇ, $3{ }^{\lambda}$, Crete, Heraklion, Voutes $\left(35^{\circ} 15^{\prime} 57.86^{\prime \prime} \mathrm{N}, 25^{\circ} 3^{\prime} 17.11^{\prime \prime E}\right)$, 24 April 2017, leg. E. Alissandrakis. Host: $†$ Ptosima undecimmaculata (Herbst, 1784) (Coleoptera: Buprestidae) on Prunus domestica.

\section{${ }^{*}$ Ecphylus silesiacus (Ratzeburg, 1848)}

Material examined. $2{ }^{\lambda}, 2$,, Crete, Heraklion, Voutes $\left(35^{\circ} 15^{\prime} 55.58^{\prime \prime} \mathrm{N}, 25^{\circ} 3^{\prime} 42.82^{\prime \prime E}\right)$, 23 May 2017, leg. E. Alissandrakis. Host: Scolytus rugulosus (Müller, 1818) (Coleoptera: Curculionidae) on Prunus domestica.

\section{*Spathius curvicaudis Ratzeburg, 1844}

Material examined. $20^{\lambda}, 5$ 우, Crete, Heraklion, Voutes $\left(35^{\circ} 16^{\prime} 8.13^{\prime \prime N}, 25^{\circ} 3^{\prime} 49.67^{\prime \prime E}\right)$, 16-22 May 2017, leg. E. Alissandrakis. Host: †Scolytus rugulosus (Müller, 1818) (Coleoptera: Curculionidae) on Prunus domestica.

\section{Subfamily Microgastrinae}

\section{Cotesia spuria (Wesmael, 1837)}

Material examined. $13 q, 50^{\lambda}$, central Greece, Dekeleia, Tatoi $\left(38^{\circ} 11^{\prime} 59.02^{\prime \prime} \mathrm{N}\right.$, 2347'40.44"E), 07 May 2016, leg. N. G. Kavallieratos, V. Žikić. Host: Diloba caeruleocephala (L., 1758) (Lepidoptera: Noctuidae) on Pyrus spinosa.

\section{Cotesia zygaenarum Marshall, 1885}

Material examined. 79 , 4 ${ }^{\prime}$, Peloponnese, Nemea $\left(37^{\circ} 50^{\prime} 14.26^{\prime \prime} \mathrm{N}, 22^{\circ} 38^{\prime} 37.33^{\prime \prime E}\right)$, 24 May 2016, leg. A. Nahirnić. Host: Zygaena lonicerae (Scheven, 1777) (Lepidoptera: Zygaenidae) on Tetragonolobus purpureus. 


\section{Diolcogaster alvearia (F., 1798)}

Material examined. $20 \circ, 7{ }^{\prime}$, Thrace, Arogi (40 $\left.57^{\prime} 20.77^{\prime \prime} \mathrm{N}, 25^{\circ} 10^{\prime} 12.08^{\prime \prime} \mathrm{E}\right), 05$ June 2005, leg. V.Žikić. Host: Peribatodes rhomboidaria (Denis \& Schiffermüller, 1775) (Lepidoptera: Geometridae) on Malus pumila; 319, 8 $0^{\lambda}$. Athens $\left(37^{\circ} 58^{\prime} 54.65^{\prime \prime N}\right.$, 2344'49.09"E), 07 May 2016, leg. V. Žikić. Host: Peribatodes rhomboidaria (Denis \& Schiffermüller, 1775) (Lepidoptera: Geometridae) on Lonicera pileata.

\section{Dolichogenidea candidata (Haliday, 1834)}

Material examined. 4q, Thessaly, Mt Pelion, Agios Ioannis $\left(39^{\circ} 24^{\prime} 58.81^{\prime \prime E}\right.$, $\left.23^{\circ} 9^{\prime} 34.27 " \mathrm{E}\right), 10$ August 2017, leg. V. Žikić. Host: Choreutis nemorana (Hübner, 1799) (Lepidoptera: Choreutidae) on Ficus carica.

\section{*Dolichogenidea longipalpis (Reinhard, 1880)}

Material examined. 3ㅇ, 10, Epirus, Mt Grammos (4021'5.95"N, 2046'43.45"E), 17 July 2003, leg. N. G. Kavallieratos. Host: $†$ Dahlica sp. Enderlein, 1912 (Lepidoptera: Psychidae) on rock.

Glyptapanteles vitripennis (Curtis, 1830)

Material examined. $3 \hat{\partial}$, central Greece, Dekeleia, Tatoi $\left(38^{\circ} 9^{\prime} 46.13^{\prime \prime} \mathrm{N}\right.$, 2347'39.34"E), 07 May 2016, leg. N. G. Kavallieratos, V. Žikić. Host: Diloba caeruleocephala (L., 1758) (Lepidoptera: Noctuidae) on Pyrus spinosa.

\section{Family Eulophidae}

Subfamily Tetrastichinae

*Melittobia acasta (Walker, 1839)

Material examined. 5q, central Greece, Dekeleia, Tatoi $\left(38^{\circ} 12^{\prime} 2.17^{\prime \prime} \mathrm{N}\right.$, 2339'53.51"E), 07 May 2016, leg. V. Žikić, N. G. Kavallieratos. Host: †Parocneria terebinthi (Freyer, 1838) (Lepidoptera: Erebidae) on Pistacia terebinthus.

\section{Family Evaniidae}

Prosevania fuscipes (Illiger, 1807)

Material examined. $3 \circ, 1 \delta^{\lambda}$, Thrace, Arogi (405 $\left.57^{\prime} 18.70^{\prime \prime N}, 25^{\circ} 10^{\prime} 6.79 " \mathrm{E}\right), 05 \mathrm{Au}-$ gust 2016, leg. V. Žikić. Host: Blatta orientalis L., 1758 (Blattodea: Blattidae). 


\section{Family Ichneumonidae}

Subfamily Banchinae

\section{Lissonota culiciformis Gravenhorst, 1829}

Material examined. $4 \sigma^{\lambda}$, central Greece, Dekeleia, Tatoi (38 $10^{\prime} 2.26^{\prime \prime} \mathrm{N}$, 2348'15.65"E), 07 May 2016, leg. N. G. Kavallieratos, V. Žikić. Host: Malacosoma neustria (L., 1758) (Lepidoptera: Lasiocampidae) on Quercus coccifera.

\section{Subfamily Campopleginae}

\section{*Campoplex difformis (Gmelin, 1790)}

Material examined. 59 , central Greece, Dekeleia, Tatoi $\left(38^{\circ} 9^{\prime} 53.71^{\prime \prime} \mathrm{N}, 23^{\circ} 49^{\prime} 11.51^{\prime \prime E}\right)$, 07 May 2016, leg. N. G. Kavallieratos, V. Žikić. Host: †Pammene oxycedrana (Millière, 1876) (Lepidoptera: Tortricidae) on Arbutus unedo; 1 , central Greece, Dekeleia, Tatoi (38 $\left.10^{\prime} 2.98^{\prime \prime N}, 23^{\circ} 49^{\prime} 40.93 " E\right), 07$ May 2016, leg. N. G. Kavallieratos, V. Žikić. Host: Archips rosana (L., 1758) (Lepidoptera: Tortricidae) on Pyrus spinosa.

\section{Subfamily Cryptinae}

\section{*Gelis albipalpus (Thomson, 1884)}

Material examined. 6q, Thessaly, Mt Pelion, Agrioleukes (39²3'13.74"N, 235'1.00"E), 11 May 2016, leg. S. Stanković, V. Žikić. Host: †Cotesia neustriae (Tobias, 1986) (Hymenoptera: Braconidae) parasitizing Lymantria dispar (L., 1758) (Lepidoptera: Erebidae) feeding on Quercus coccifera.

\section{Gelis areator (Panzer, 1804)}

Material examined. 3, $10^{\lambda}$, Thessaly, Mt Pelion, Agrioleukes $\left(39^{\circ} 23^{\prime} 15.16^{\prime \prime} \mathrm{N}\right.$, 235'1.36"E), 11 May 2016, leg. S. Stanković, V. Žikić. Host: †Cotesia neustriae (Tobias, 1986) parasitizing Lymantria dispar (L., 1758) (Lepidoptera: Erebidae) feeding on Quercus coccifera.

\section{Gelis ilicicola (Seyrig, 1927)}

Material examined. 4q, Thessaly, Mt Pelion, Agrioleukes (39²3'16.90"N, 235'3.91"E), 11 May 2016, leg. S. Stanković, V. Žikić. Host: Cotesia neustriae (Tobias, 1986) parasitizing Lymantria dispar (L., 1758) (Lepidoptera: Erebidae) feeding on Quercus coccifera. 


\section{*Lysibia tenax Townes, 1983}

Material examined. 129 , 9 $0^{\lambda}$, central Greece, Dekeleia, Tatoi $\left(38^{\circ} 10^{\prime} 53.42 " \mathrm{~N}\right.$, 2346'50.76"E), 07 May 2016, leg. N. G. Kavallieratos, V. Žikić. Host: †Cotesia neustriae (Tobias, 1986) parasitizing Lymantria dispar (L., 1758) (Lepidoptera: Erebidae) feeding on Quercus coccifera L.

\section{Subfamily Pimplinae}

\section{Itoplectis tunetana (Schmiedeknecht, 1914)}

Material examined. 69, Thessaly, Mt Pelion, Agios Ioannis $\left(39^{\circ} 25^{\prime} 9.74 " \mathrm{~N}\right.$, $\left.23^{\circ} 9^{\prime 2} 21.43 " \mathrm{E}\right), 10$ August 2017, leg. V. Žikić. Host: Choreutis nemorana (Hübner, 1799) (Lepidoptera: Choreutidae) on Ficus carica.

\section{Family Tachinidae \\ Subfamily Exoristinae}

Exorista segregata (Rondani, 1859)

Material examined. $4{ }^{\prime}$, central Greece, Dekeleia, Tatoi $\left(38^{\circ} 9^{\prime} 23.16^{\prime \prime} \mathrm{N}, 23^{\circ} 45^{\prime} 3.40 " \mathrm{E}\right)$, 07 May 2016, leg. N. G. Kavallieratos, V. Žikić. Host: Parocneria terebinthi (Freyer, 1838) (Lepidoptera: Erebidae) on Pistacia terebinthus.

\section{Discussion}

Our findings revealed that the subfamily Charmontinae is represented by C. cruentatus, which is a solitary parasitoid of several microlepidopterans (van Achterberg 1979; Yu et al. 2012) and is recorded in Greece for the first time. The only identified species of the subfamily Cheloninae, C. sulcatus, is a parasitoid of several microlepidopterous insects (Aydogdu and Beyarslan 2006). It is an important natural enemy of Prays citri (Millière, 1873) (Lepidoptera: Praydidae), a pest of citrus that is common in the Mediterranean region (Moreno et al. 1990). Most likely, this moth has been introduced in the Mediterranean region from Africa with the import of citrus propagating material (de Carvalho and Aguiar 1997). The evaluation of C. sulcatus as a biological control agent against $P$. citri could be of interest, given that this parasitoid species is widely spread in the Palaearctic (Aydogdu and Beyarslan 2006).

One of the largest braconid subfamily, Microgastrinae, is specialized on the parasitization of caterpillars (Shaw and Huddleston 1991). Both identified species of Cotesia Cameron (C. spuria and C. zygaenarum) are gregarious endoparasitoids of cater- 
pillars (Žikić et al. 2013; Gadallah et al. 2015). Cotesia spuria is a polyphagous and cosmopolitan species that inhabits whole Palaearctic (Yu et al. 2012; Gadallah et al. 2015). During our study we identified C. spuria parasitizing caterpillars of D. caeruleocephala, which is recognized as a pest in orchards of the family Rosaceae (Bolu and Özgen 2007). Cotesia zygaenarum is an oligophagous parasitoid of the genus Zygaena F. and several other lepidopterous genera (Gadallah et al. 2015). Another gregarious parasitoid identified in this study, $D$. alvearia, has a very narrow host range which includes 9 taxa of coleopterous, hymenopterous and lepidopterous insects commonly found in Europe (Gadallah et al. 2015). The controversial genus Dolichogenidea Viereck, which is hardly separated from Apanteles Foerster (sensu stricto) (Fernández Triana et al. 2014), predominantly contains both solitary and gregarious endoparasitoids of microlepidoptera (i.e., Gracillariidae, Plutellidae, Pyralidae, Tortricidae, Yponomeutidae) (Medvedev 1989; Jankowska and Wiech 2006). Glyptapanteles vitripennis is a gregarious parasitoid with broad host range that includes major pests in forest and agricultural ecosystems, e.g., L. dispar, M. neustria, Yponomeuta malinellus Zeller, 1838 (Lepidoptera: Yponomeutidae) (Yu et al. 2012). Interestingly, this species emerged from $D$. caeruleocephala caterpillars under no evident superparasitism because some other caterpillars were parasitized by $C$. spuria.

The subfamily Doryctinae includes species that parasitize wood-feeding coleopterans, including Curculionidae (Scolytinae), Bostrychidae, Buprestidae and Cerambycidae (Farahani et al. 2014). Ptosima undecimmaculata is identified for the first time as a host of $D$. protuberans in our study. Larvae of $P$. undecimmaculata live inside wood of dead trees and living branches of different species of Prunus spp. for 2-3 years (Sakalian 2003). Moreover, with the exception of Dolichomitus tuberculatus (Geoffroy, 1785) (Hymenoptera: Ichneumonidae), parasitoids of this species have not been previously recorded (Aliyev and Maharramova 2009). Dendrosoter protuberans is an oligophagous ectoparasitoid recorded from numerous hosts, mainly Curculionidae, e.g., Hylesinus F., Leperisinus Reitter, Phloeosinus Chapuis, Phloeotribus Latreille, Scolytus Geoffroy, Tomicus Latreille, and also from few Buprestidae, Cerambycidae and Chrysomelidae (Wegensteiner et al. 2015; Beyarslan 2017). This parasitoid species is a very important natural enemy of Scolytus multistriatus (Marsham, 1802) (Coleoptera: Curculionidae) that seriously attacks elm trees in Europe (Manojlović et al. 2003). The genus Ptosima Solier is solely represented in Europe by $P$. undecimmaculata with two subspecies; Ptosima undecimmaculata ssp. metallescens Bily, 1982 (Coleoptera: Buprestidae) which is only found in Crete, and Ptosima undecimmaculata ssp. undecimmaculata (Herbst, 1784) (Coleoptera: Buprestidae) which is dispersed in the rest of Greece and Europe (van Achterberg 2013). Besides D. protuberans, two more species of the genus Dendrosoter Wesmael have been reported in Europe, i.e., Dendrosoter curtisii (Ratzeburg, 1848) (Coleoptera: Buprestidae) and Dendrosoter middendorffi (Ratzeburg, 1848) (Coleoptera: Buprestidae) (van Achterberg 2013), which have been supplemented by $E$. silesiacus and $S$. curvicaudis as new members of the Greek fauna recorded in our study. The fact that $S$. curvicaudis is recorded for the first time from larvae of $S$. rugulosus in cut woods of $P$. domestica may open a new path towards the biological control 
of this serious scolytid pest of fruit and nut trees (Seybold et al. 2016), whose chemical control is not effective when S. rugulosus is inside wood (Fox 2015).

With few exceptions, T. thoracica is a specialized parasitoid of the genus Bruchus L., which includes various species of economic importance for stored legumes (Parker 1957; Reddy et al. 2018). This species belongs to the subfamily Brachistinae that includes endoparasitoids of various beetles (Belokobylskij 1998). Several species oviposit inside eggs and emerge from larvae of their hosts, becoming therefore egg-larval parasitoids (Shaw and Huddleston 1991). Triaspis thoracica acts that way leading to successful biological control of the noxious B. pisorum (Clausen 1954; Nikolova 2016).

Out of the five ensign wasp species inhabiting Europe, four are recorded in Greece, these are: Evania appendigaster (L., 1758), P. fuscipes, Prosevania incerta (Kieffer, 1904) and Zeuxevania splendidula (Costa, 1884) (van Achterberg 2013). These wasps are specialized parasitoids of oothecae of Blattodea (Cameron 1957; Carlson 1979). Prosevania fuscipes has been recorded in several European countries, but most likely it occurs in all countries where its host, B. orientalis, is present (Ceianu 1986). The only identified member of the family Eulophidae, $M$. acasta, is a gregarious ectoparasitoid of insects belonging to various orders (Browne 1922) (i.e., Hymenoptera, Diptera, Lepidoptera and Coleoptera); it was reared from P. terebinthi, which constitutes a new host record.

We also identified seven parasitoid species that belong to the largest hymenopterous family, the Ichneumonidae. Itoplectis tunetana is primary endoparasitoid of lepidopterous larvae or pupae, while $C$. difformis and L. culiciformis emerge from lepidopterous larvae (Georgiev 2000; Talebi et al. 2005; Yu et al. 2012; Žikić et al. 2017). Lysibia tenax is a specialized hyperparasitoid of the genus Cotesia, while $C$. neustriae is a newly recorded host for this species. The remaining three ichneumonids belong to genus Gelis Thunberg and behave either as primary parasitoids or hyperparasitoids; this type of strategy is usual for most of the members of this genus (Žikić et al. 2017). As a secondary parasitoid, G. albipalpus has been recorded only from Apanteles murinanae Čapek \& Zwölfer, 1957 (Hymenoptera: Braconidae) (Čapek and Zwölfer 1957), and therefore, C. neustriae is listed for the first time as a host. The polyphagous $G$. aerator, having a host range that exceeds 180 species (Yu et al. 2012), was found for first time parasitizing also C. neustriae. Out of about 25 braconid species on the list of hosts of $G$. aerator, there are 12 species of the genus Cotesia (Yu et al. 2012). Prior to the revision by Schwarz (2016) of the macropterous females of genus Gelis from the Western Palaearctic, G. ilicicola was often mixed with related species and thus most records are not reliable. However, Schwarz (2016) reported that specimens of G. ilicicola reared from small lepidopterans (Coleophoridae), neuropterans (Chrysopidae) and hymenopterans (Braconidae: Microgastrinae), suggesting that this species is a parasitoid of a wide range of small cocoons and cocoon-like structures. This hypothesis posits additional investigation provided that the ability of a parasitoid to attack the immobile life stages of host species may have some advantages for its use in biological control. For example, in several cases, larvae choose a site to pupate other than the original feeding one, where they are parasitized by pupal parasitoids (Hawkins 1994; Cancino et al. 2012). In this way, pupal parasitoids restrict the suitable locations for insects' development (Machtinger et al. 2015). 
The only identified species of the family Tachinidae in our study is E. segregata. This is a common parasitoid of numerous lepidopterous species (Mückstein et al. 2007). Until now, it has been reared from over 50 species belonging to the Erebidae, such as L. dispar, and the Lasiocampidae, such as $M$. neustria, but also from many belonging to the Noctuidae, Thaumetopoeidae and Zygaenidae (Tschorsnig 2017, Žikić et al. 2017). Exorista segregata has a relatively wide geographical range, and it has been recorded in most European countries but also in the North Africa, Anatolia and the USA (Tschorsnig 1997).

Our findings shed light on a greatly overlooked issue, which is the fauna of parasitoids occurring in Greece. The several new recorded parasitoid species in Greece and the previously unknown parasitoid-host associations indicate the high level of biodiversity that exists in the investigated ecosystems and potentially triggers natural biological control of several harmful insect species. The recorded elevated richness of beneficial insects makes us hypothesize that additional natural enemies may occur in the same or similar ecosystems, a premise that should be further investigated and also confirmed with additional field surveys. Furthermore, a common practice of pests' management deals with their identification and the application of chemical compounds without considering the role of the existing beneficial fauna (Mehle and Trdan 2012). Our study clearly shows that the overlooked intermediate stage of identification of parasitoids is also crucial, as it can bring to light the high level of activity of these species against pests. More carefully designed pest management strategies would be modelled towards the conservation of the local parasitoid species.

\section{Acknowledgments}

This study was partially supported by the Ministry of Education, Science and Technological Development of the Republic of Serbia (Grant Number III43001).

\section{References}

Alissandrakis E, Psirofonia P, Kavallieratos NG, Stanković SS, Žikić V (2018) Parasitic wasps related to Prays oleae (Bernard, 1788) (Lepidoptera: Praydidae) in olive orchards in Greece. ZooKeys 773: 143-154. https://doi.org/10.3897/zookeys.773.25402

Aliyev A, Maharramova S (2009) Ichneumonidae in the collection of the Institute of Zoology, NAS of Azerbaijan Republic. Part I. Subfamily Pimplinae (Hymenoptera). Beiträge zur Entomologie 59: 271-286. https://doi.org/10.21248/contrib.entomol.59.2.271-286

Anagnou Veroniki M, Kontodimas DC, Kavallieratos NG, Doukas D, Staroyiannis G, Tomanović Ž (2006) Data on phenology, parasitism and control of citrus leaf miner Phyllocnistis citrella Stainton (Lepidoptera: Gracillariidae), in Greece. Archives of Biological Sciences 58: 239-244. https://doi.org/10.2298/ABS0604239V

Aydogdu M, Beyarslan A (2006) Microchelonus Szépligeti 1908 (Hymenoptera: Braconidae: Cheloninae) species from the Marmara, western and Blacksea regions of Turkey. Linzer biologische Beiträge 38: 397-407. 
Barbosa P (1998) Agroecosystems and conservation biological control. In: Barbosa P (Ed.) Conservation biological control. Academic Press, San Diego, 39-54. https://doi.org/10.1016/ B978-012078147-8/50049-9

Belokobylskij SA (1998) Subfam. Brachistinae (Calyptinae). In: Lehr PA (Ed.) Keys to Insects of the Russian Far East. Neuropteroidea, Mecoptera, Hymenoptera, Volume 4. Dal'nauka, Vladivostok, 440-489.

Beyarslan A (2017) Checklist of Turkish Doryctinae (Hymenoptera: Braconidae). Linzer biologische Beiträge 49: 415-440.

Bolu H, Özgen İ (2007) Life History and Biology of Diloba caeruleocephala (Figure of Eight) (Lepidoptera: Noctuidae). Belgian Journal of Zoology 137: 133-136.

Broad G (2011) Identification key to the subfamilies of Ichneumonidae (Hymenoptera). Natural History Museum, London, 40 pp.

Browne FB (1922) On the life-history of Melittobia acasta, Walker; a chalcid parasite of bees and wasps. Parasitology 14: 349-370. https://doi.org/10.1017/S003118200001026X

Čapek M, Zwölfer H (1957) Apanteles murianae nov. spec. (Braconidae: Hym.), ein neuer parasit des tannentriebwicklers. Bulletin de la Société Entomologique Suisse 30: 119-126. http://doi.org/10.5169/seals-401304

Cameron E (1957) On the parasites and predators of the cockroach. II - Evania appendigaster (L.). Bulletin of Entomological Research 48: 199-209. http://doi.org/10.1017/ S0007485300054171

Cancino J, Liedo P, Ruiz L, López G, Montoya P, Barrera JF, Sivinski J, Aluja M (2012) Discrimination by Coptera haywardi (Hymenoptera: Diapriidae) of hosts previously attacked by conspecifics or by the larval parasitoid Diachasmimorpha longicaudata (Hymenoptera: Braconidae). Biocontrol Science and Technology 22: 899-914. http://doi.org/10.1080/0 9583157.2012.696088

Carlson RW (1979) Superfamily Evanioidea. In: Krombein KV, Hurd PD, Smith DR, Burks BD (Eds) Catalogue of Hymenoptera in America North of Mexico, Volume 1, Symphyta and Apocrita (Parasitica). Smithsonian Institution Press, Washington DC, 1109-1118.

de Carvalho JP, Aguiar AMF (1997) Pragas dos citrinos na ilha da Madeira. Direcção Regional de Agricultura da Região Autónoma da Madeira, Madeira, 410 pp.

Ceianu C (1986) Two parasites of Blatta orientalis L. oothecae: Tetrastichus hagenowii (Ratzeburg) (Hymenoptera: Eulophidae) and Prosevania fuscipes (Illiger) (Hymenoptera: Evaniidae). Archives Roumaines de Pathologie Expérimental et de Microbiologie 45: 161-167.

Clausen CP (1954) The egg-larval host relationship among the parasitic Hymenoptera. Bollettino del Laboratorio di Zoologia Generale e Agraria della Facoltà Agraria in Portici 33: 119-133.

Devetak M, Bohinc T, Kač M, Trdan S (2014) Seasonal dynamics of the cabbage armyworm (Mamestra brassicae [L.]) and the bright-line brown-eyes moth (Mamestra oleraceae [L.]) in Slovenia. Horticultural Science 41: 80-88. http://doi.org/10.17221/209/2013-HORTSCI Elkinton JS, Liebhold AM (1990) Population dynamics of gypsy moth in North America. Annual Review of Entomology 35: 571-596. http://doi.org/10.1146/annurev. en.35.010190.003035 
Farahani S, Talebi AA, Rakhshani E (2014) Wasps of the subfamily Doryctinae (Hymenoptera: Braconidae) in Iran. Zoology in the Middle East 60: 65-81. https://doi.org/10.1080/093 97140.2014 .892341

Fernández Triana J, Whitfield J, Rodriguez J, Smith M, Janzen D, Hajibabaei M, Burns J, Solis A, Brown J, Cardinal S, Goulet H, Hebert P (2014) Review of Apanteles sensu stricto (Hymenoptera, Braconidae, Microgastrinae) from Area de Conservación Guanacaste, northwestern Costa Rica, with keys to all described species from Mesoamerica. ZooKeys 383: 1-565. https://doi.org/10.3897/zookeys.383.6418

Fox R (2015) The Gardener's Book of Pests and Diseases. The Complete Diagnostic guide. Batsford, London, $211 \mathrm{pp}$.

Gadallah NS, Ghahari H, Peris Felipo FJ (2015) Catalogue of the Iranian Microgastrinae (Hymenoptera: Braconidae). Zootaxa 4043: 1-69. http://doi.org/10.11646/zootaxa.4043.1.1

Gagić V, Petrović Obradović O, Fründ J, Kavallieratos NG, Athanassiou CG, Starý P, Tomanović $\check{Z}$ (2016) The effects of aphid traits on parasitoid host and specialist advantage. Plos ONE 11(6): e0157674. http://doi.org/10.1371/journal.pone.0157674

Georgiev G (2000) Studies on larval parasitoids of Paranthrene tabaniformis (Rott.) (Lepidoptera: Sesiidae) on urban poplars (Populus spp.) in Sofia, Bulgaria. Annals of Forest Science 57: 181-186. http://doi.org/10.1051/forest:2000168

Goulet H, Huber JT (1993) Hymenoptera of the World: an Identification Guide to Families. Agriculture Canada, Ottawa, 668 pp.

Godfray HCJ (1994) Parasitoids: Behavioral and Evolutionary Ecology. Princeton University Press, Princeton, New Jersey, 488 pp.

Hassell MP (1980) Foraging strategies, population models and biological control: a case study. Journal of Animal Ecology 49: 603-628. https://doi.org/10.2307/4267

Hassell MP, May RM (1986) Generalist and specialist natural enemies in insect predator-prey interactions. Journal of Animal Ecology 55: 923-940. https://doi.org/10.2307/4425

Hawkins BA (1994) Pattern and Process in Host-parasitoid Interactions. Cambridge University Press, Cambridge, 190 pp. https://doi.org/10.1017/CBO9780511721885

Jankowska B, Wiech K (2006) The composition and role of parasitoids in reducing population densities of diamondback moth Plutella xylostella L. on different cabbage vegetables. Journal of Plant Protection Research 46: 275-284.

Kavallieratos NG, Tomanović Ž, Sarlis GP, Fasseas C, Emmanouel NE (2006) A review of the genus Aphidius Nees in Greece (Hymenoptera: Braconidae: Aphidiinae) with the description of a new species. Journal of Natural History 40: 1179-1197. http://doi. org/10.1080/00222930600822555

Kavallieratos NG, Tomanović Ž, Starý P, Athanassiou CG, Sarlis GP, Petrović O, Niketić M, Anagnou Veroniki M (2004) A survey of aphid parasitoids (Hymenoptera: Braconidae: Aphidiinae) of Southeastern Europe and their aphid-plant associations. Applied Entomology and Zoology 39: 527-563. http://doi.org/10.1303/aez.2004.527

Kavallieratos NG, Tomanović Ž, Starý P, Mitrovski Bogdanović A (2008) Parasitoids (Hymenoptera: Braconidae: Aphidiinae) attacking aphids feeding on Prunoideae and Maloideae crops in Southeast Europe: aphidiine-aphid-plant associations and key. Zootaxa 1793: 47-64. 
Kavallieratos NG, Tomanović Ž, Petrović A, Janković M, Starý P, Yovkova M, Athanassiou CG (2013) Review and key for the identification of parasitoids (Hymenoptera: Braconidae: Aphidiinae) of aphids infesting herbaceous and shrubby ornamental plants in southeastern Europe. Annals of the Entomological Society of America 106: 294-309. http://doi. org/10.1603/AN12090

Kavallieratos NG, Tomanović Ž, Petrović A, Kocić K, Janković M, Starý P (2016) Parasitoids (Hymenoptera: Braconidae: Aphidiinae) of aphids feeding on ornamental trees in southeastern Europe: key for identification and tritrophic associations. Annals of the Entomological Society of America 109: 473-487. http://doi.org/10.1093/aesa/saw003

Kolarov J (2007) A catalogue of the Ichneumonidae from Greece (Greece). Entomofauna 28: 441-488.

Krantz GW (1978) A Manual of Acarology. Second Edition. Oregon State University Book Stores, Corvallis, Oregon, 509 pp.

Machtinger ET, Geden CJ, Kaufman PE, House AM (2015) Use of pupal parasitoids as biological control agents of filth flies on equine facilities. Journal of Integrated Pest Management 6(1): 16. http://doi.org/10.1093/jipm/pmv015

Manojlović B, Zabel A, Perić P, Stanković S, Rajković S, Kostić M (2003) Dendrosoter protuberans (Hymenoptera: Braconidae), an important elm bark beetle parasitoid. Biocontrol Science and Technology 13: 429-439. http://doi.org/10.1080/0958315031000124486

Medvedev GS (1989) Keys to the Insects of the European Part of the USSR, Volume 4. Lepidoptera. Part 2. Brill EJ, Leiden, 1060 pp.

Mehle N, Trdan S (2012) Traditional and modern methods for the identification of thrips (Thysanoptera) species. Journal of Pest Science 85: 179-190. https://doi.org/10.1007/ s10340-012-0423-4

Moreno J, Falcó JV, Jiménez R (1990) Study of the parasitoid complex of Prays citri Mill. (Lepidoptera: Hyponomeutidae) in the south of the Alicante province. Boletín de Sanidad Vegetal Plagas 16: 515-522.

Mückstein P, Tschorsing HP, Vaňhara J, Michalková V (2007) New host and country records for European Tachinidae. Entomologica Fennica 18: 179-183. http://doi.org/10.1017/ S0007485315001133

Nikolova I (2016) Pea weevil damage and chemical characteristics of pea cultivars determining their resistance to Bruchus pisorum L. Bulletin of Entomological Research 106: 268-277. http://doi.org/10.1017/S0007485315001133

Papp J (2007) Braconidae (Hymenoptera) from Greece, 6. Notes fauniques de Gembloux 60: 99-127.

Parker HL (1957) Notes sur quelques bruches et leurs parasites élevés des graines de Légumineuses. Bulletin de la Société Entomologique de France 62: 168-179.

Petrović A, Mitrović M, Ghaliow ME, Ivanović A, Kavallieratos NG, Starý P, Tomanović Ž (2019) Resolving the taxonomic status of biocontrol agents belonging to the Aphidius eadyi species group (Hymenoptera: Braconidae: Aphidiinae): an integrative approach. Bulletin of Entomological Research. http://doi.org/10.1017/S000748531800055X

Reddy GVP, Sharma A, Gadi RL (2018) Biology, ecology, and management of the pea weevil (Coleoptera: Chrysomelidae). Annals of the Entomological Society of America 111: 161-171. https://doi.org/10.1093/aesa/sax078 
Sakalian VP (2003) A Catalogue of the Jewel Beetles of Bulgaria (Coleoptera: Buprestidae). Pensoft Publishers, Sofia, 246 pp.

Seybold SJ, Penrose, RL, Graves AD (2016) Invasive bark and ambrosia beetles in California Mediterranean forest ecosystems. In: Paine TD, Lieutier F (Eds) Insects and Diseases of Mediterranean Forest Systems. Springer, Cham, 583-662. https://doi.org/10.1007/9783-319-24744-1_21

Schwarz M (2016) The ichneumonid genus Gelis (Hymenoptera: Ichneumonidae: Cryptinae) with macropterous females in the western Palaearctic region. Linzer biologische Beiträge 48: 1677-1752.

Shaw MR, Huddleston T (1991) Classification and Biology of Braconid Wasps. Handbooks for the Identification of British Insects, Volume 7. Natural Museums Scotland, Edinburgh, 126 pp.

Talebi AA, Rakhshani E, Daneshvar S, Fathipour Y, Moharamipour S, Horstman K (2005) Report of Campoplex tumidulus and Itoplectis tunetana (Hymenoptera: Ichneumonidae), parasitoids of Yponomeuta malinellus Zell. (Lepidoptera: Yponomeutidae) from Iran. Applied Entomology and Phytopathology 73: 134-138.

Tobias VI, Jakimavicius AB (1986) Family Braconidae. In: Medvedev GS (Ed.) A Key to Insects of the European Part of the USSR, Volume 3. Hymenoptera. Part 5. Nauka, Leningrad, 7-231, 284-292, 296-299.

Tomanović Ž, Petrović A, Mitrović M, Kavallieratos NG, Starý P, Rakhshani E, Rakhshanipour M, Popović A, Shukshuk AH, Ivanović A (2014) Molecular and morphological variability within the Aphidius colemani group with redescription of Aphidius platensis Brethes (Hymenoptera: Braconidae: Aphidiinae). Bulletin of Entomological Research 104: 552-565. https://doi.org/10.1017/S0007485314000327

Tsankov G, Douma Petridou E, Mirchev P, Georgiev G, Kousaftikis A (1999) Spectrum of egg parasitoids and rate of parasitism of egg batches of the pine processionary moth Thaumetopoea pityocampa (Den. \& Schiff.) in the northern Peloponnes/Greece. Journal of the Entomological Research Society 1: 1-8.

Tschorsnig HP (2017) Preliminary host catalogue of Palaearctic Tachinidae (Diptera). http:// www.nadsdiptera.org/Tach/WorldTachs/CatPalHosts/Cat_Pal_tach_hosts_Ver1.pdf [Accessed on: 2018-9-26]

Tschorsnig HP (1997) Tachinidae (Diptera) recorded from the Swiss National Park and adjacent areas, collected by Fred Keiser. Mitteilungen der Schweizerischen Entomologischen Gesellschaft 70: 101-116.

Tschorsnig HP, Herting B (1994) The Tachinids (Diptera: Tachinidae) of Central Europe: Identification Keys for the Species and Data on Distribution and Ecology. State Museum of Natural Science, Stuttgart, 150 pp.

van Achterberg C (1979) A revision of the subfamily Zelinae auct. (Hymenoptera: Braconidae). Tijdschrift voor Entomologie 122: 1-28.

van Achterberg K (2013) Fauna Europaea: Hymenoptera, Braconidae. Fauna Europaea version 2.6.2. http://faunaeur.org/ [Accessed on: 2018-9-26]

Wegensteiner R, Wermelinger B, Herrmann M (2015) Natural enemies of bark beetles: predators, parasitoids, pathogens, and nematodes. In: Vega FE, Hofstetter RW (Eds) Bark Beetles: Biology and Ecology of Native and Invasive Species. Elsevier, Oxford, 247-304. 
Yu DS, van Achterberg C, Horstmann K (2012) Taxapad 2012, Ichneumonoidea 2011. Database on flash-drive. Ottawa, Ontario.

Zeegers T (2017) New and interesting Tachinidae from Greece. Tachinid Times 30: 21-25.

Žikić V, Stanković SS, Petrović A, Ilić Milošević M, van Achterberg K (2013) Parasitoid complex of Zygaena filipendulae L. (Lepidoptera: Zygaenidae). Archives of Biological Sciences 63: 1027-1035. https://doi.org/10.2298/ABS1303027Z

Žikić V, Stanković SS, Kavallieratos NG, Athanassiou CG, Georgiou, P, Tschorsing HP, van Achterberg C (2017) Parasitoids associated with Lymantria dispar (Lepidoptera: Erebidae) and Malacosoma neustria (Lepidoptera: Lasiocampidae) in Greece and comparative analysis of their parasitoid spectrums in Europe. Zoologischer Anzeiger 270: 166-175. https://doi. org/10.1016/j.jcz.2017.10.006 